管説

\title{
噴門癌の非開胸的手術における吊り上げ式開腹器と 自動吻合器の応用
}

一噴門癌の非開胸的手術一

\begin{tabular}{|c|c|c|c|c|c|c|c|c|c|}
\hline \multicolumn{5}{|c|}{ 能本大学医学部第 2 外科 } & \multicolumn{5}{|c|}{ （主任：赤木正信教授） } \\
\hline 隅 & 厚 & 信 & $\equiv$ & 隅 & 克 & 毅 & 馬 & 場 & 憲一郎 \\
\hline 木 & 泰 & 志 & 稲 & 森 & 洋 & 平 & 跡 & 部 & 安 \\
\hline 藤 & 浩 & 幸 & 前 & 野 & 正 & 伸 & 高 & 野 & \\
\hline 田 & 和 & 則 & 村 & 上 & 明 & 利 & 片 & 㴊 & \\
\hline 村 & 正 & 憲 & 有 & 馬 & 幸 & 一 & 本 & 明 & \\
\hline 本 & 誠 & - & 島 & 田 & 信 & 也 & 守 & 安 & 直佐 \\
\hline 田 & 将 & & & & & & & & \\
\hline
\end{tabular}

\footnotetext{
社会保険組合天草中央病院

島村 曋 臣正口健男
}

食道に浸潤を認める噴門癌の根治手術においては，下縱隔リンハ節への転移がみられ るので，腹部のみならずこれら胸部の邡清と十分な食道切除を行なら必要がある。教室 では, 従来主として噴門癌の食道内進展, 癌の食道内進展距離 $(\mathrm{E})>2 \mathrm{~cm}$ の場合には積 極的に右開胸的フプローチを採用してきた。

最近, 森岡式吊り上げ式開腹器を用いて悸肋部を斜め上に牽引し, 食道裂孔部より前 方に向かって横隔膜を数 $\mathrm{cm}$ 切開して裂孔部を開大すると, 開腹操作のみで（非開胸的 に)綎隔内の広い視野が得られ，下綎隔リンバ節の廓清と広範な食道妡除が容易になり， さらに, EEA 型吻合器による器械吻合を応用すると, 綎隔内ことに中・下部食道の部位 での吻合も可能となった。

現在では, 食道内癌進展距離 $\mathrm{E}<3 \mathrm{~cm}$ の噴門癌に対しては原則として本術式を施行し ている。過去 3 年余に括ける41例の噴門癌のうち非開胸例が36例であり,このらち EEA 非使用が14例, 使用が22例，開胸が 5 例である。㭪後合併症のらち䋖合不全は EEA 非使 用例で7.1\%にみられたが, EEA 使用例と開胸例ではみられず, また, 肺合併症の発生率 は EEA 非使用例で7.1\%，使用例で $13.6 \%$ ，開胸例では $20.0 \%$ あった。

このように, 本術式は非開胸下に綖隔下部に到達でき, また術後合併症の発生率む比 較的少なく，噴門癌に対して有用である。

索引用語：噴門（部）癌非開胸術式, 吊り上げ式開腹器, EEA 式自動吻合器

\section{はじめに}

食道に漫潤を認める隫門癌の根治手術においては, 下縰隔（No. 108, 110,111, 112）リンハ節厚清と十分 な食道切除を行なら必要があり, その到達法としては おおまかに開腹, 胸骨粉切開, 左開胸および右開胸が ある.

敖室では，従来主として噴門癌の食道内進展, リン
バ節転移および手術成積の検討から, 癌の食道内進展 距離 $(\mathrm{E})<1 \mathrm{~cm}$ では非開胸， $\mathrm{E}>2 \mathrm{~cm}$ の場合には積極 的に右開胸的アプローチを採用してきだ.

しかし, 最近森岡式吊り上げ式開腹器2゙使用する ことにより，腹腔操作のみで綎隔内の広い、視野が得ら れ、下綎隔リンパ節の遊清之広範な食道切除が容易に なり,さらに EEA 型自動吻合器による器械吻合を応 
表 1 本術式の道応

\begin{tabular}{|c|c|}
\hline 食道内被進展距離 & 式 \\
\hline$E>3 \mathrm{~cm}$ & 開胸(ことに右用胸) \\
\hline $\mathrm{E}<3 \mathrm{~cm}$ & 非開胸 (つり上げ式開腹器+器械吻合) \\
\hline$E<2 \mathrm{~cm}$ & "（つり上げ式開腹器） \\
\hline$E<1 \mathrm{~cm}$ & "（必ずしも必要としない） \\
\hline
\end{tabular}

用すると縦隔内ことに中部食道 (Im 部あたり)での吻 合す可能となった。したがって，現在では表 1 のごと 〈 ${ }^{3)}, \mathrm{E}<3 \mathrm{~cm}$ の噴門癌に対しては原則として非開胸的 に行なっており，良好な手術成績をあげているのでそ の手術手技および利点について述べてみたい.

\section{手術手技}

\section{1. 開腹}

剣状突起から脐下 $2 \sim 3 \mathrm{~cm}$ に達する上腹部正中切開 にて開腹する，剣状突起のところではその左側を上方 は横隔膜付着部まで十分切り上げる，吊り上げ式開腹 器（図 1）を装着するときに肝を損傷しないようにす るために肝円靬帯および肝鎌状靬帯を切離する。

開腹したら，吊り上げ式開腹器を装着する（図 2). 手術野はその殆どが正中より左側にあるので，左側の 悸助部を右側上りも多少強く吊り上げる万がよい。な お，本開腹器の使用時間をできるだけ短維するために， 不必要なときには吊り上げ鈎の鎖を外しておく。

ます， S, P, H, N 因子について，腹腔内をくまなく 精查する，根治手術が可能であると判断したら，肝左 葉の三角勒帯を横隔膜付着部から電気人スを用いて切 醀する，予定術式が噴門側胃切除の場合は，まず第一 に. 幽門下 (No. 6) リンパ節扰よび右大弯 (No.4d) リンハ節の転移の有無を調べる。ここに転移が認めら れれば，胃全摘術に変更しなければならないままた， 転移がなくても，肛門側の切離線からみて幽門側残胃 が過小であると判断されるときには，術後残胃機能を 期待し難く，むしろ胃全摘訹の方が術後愁訴の面から も好まし(、45)と思われる。

2. リンパ節麻清と胃切除

a）噴門側胃切除術：胃大網動脈に沿ってNo. 6fo 上びNo. 4d リンバ節を廓清しながら，胃大網動脈か ら大網を切離し，左右胃大網動脈の分岐部まで進める。 また，大網とともに横行結腸間膜扰よび苹被膜を剥離 ないし切離する。必要に応してて中結腸動脈周囲（No. 15）括よび腸間膜根部（No. 14）リンパ節を廓清する がここれらは噴䦦癌ではN3の（）ないしN4群であ ク，その廟清は絶対的なものではなく，ことに噴門側

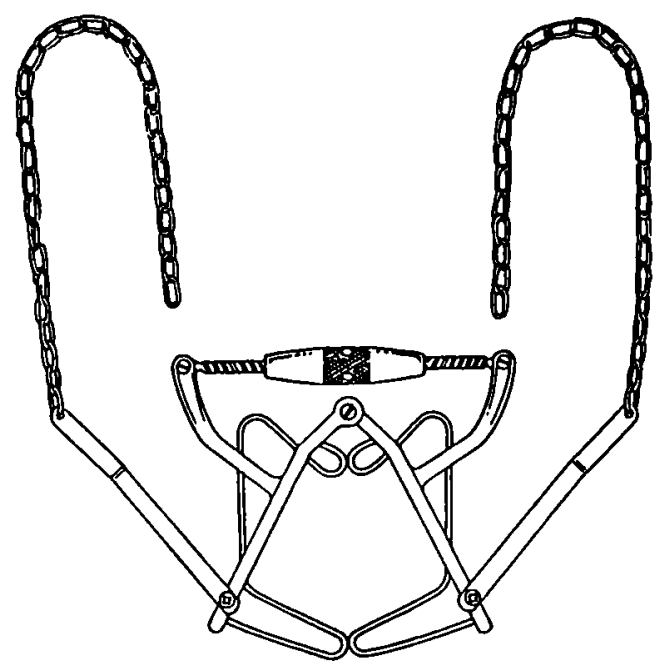

图 1 森周式吊ク上げ式開腹器

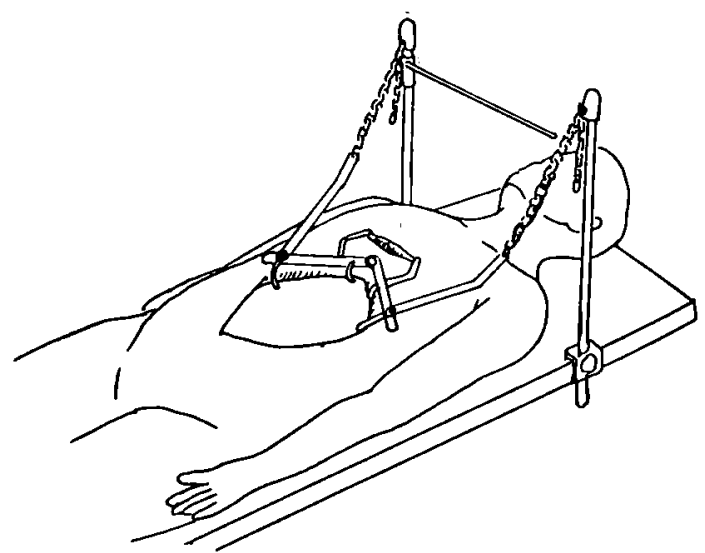

図 2 吊り上げ式開腹器の葧着

胃切除術ではその必要性は少ない。

次に，十二指腸の外側で後腹膜を剝がし，Kocherの 十二指腸授動術を十分に行ない，朠頭部扰よび下大静 脈を露出する。また，肝十二指腸勒帯を肝近くで開き， 右胃動脈を結禁・切離し，胓後部（No. 13）リン八節 およひ勒帯内（No. 12）リンバ節の倣清を行な5。さ らに，苹の上縁に沿って総肝動脈幹（No. 8）リンバ節 を鄐清し, 左胃動脈根部, 総肝動脈根部およひ脾動脈 根部の腹腔動脈周囲（No. 9）リンバ節廓清を行なら. この際,この部位の転移ないし漫潤が著明で，左胃動 脈の処理が困難なときには，脾を脱転し食道も切離し た後で操作する．左胃動脈の処理が終わったら，その まま食道裂孔に向かって操作を進める。ここで，横隔 膜裂孔を前方に約 $3 \sim 4 \mathrm{~cm}$ 切開して裂孔部を開大寸る 


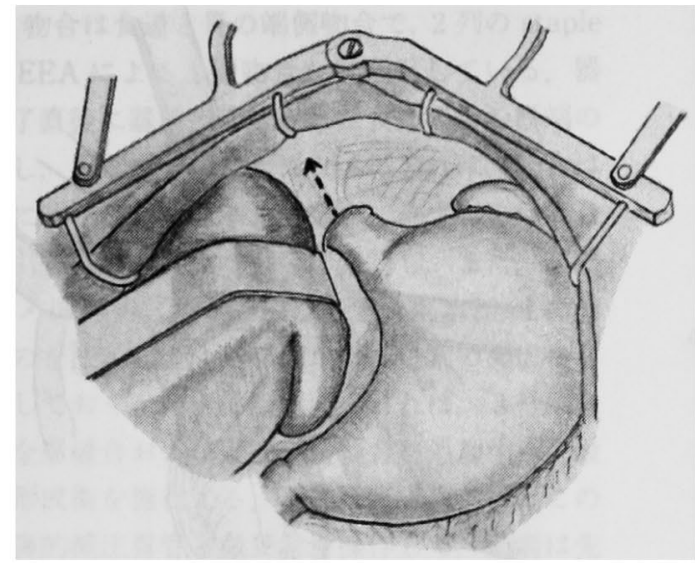

a. 横隔膜の食道裂孔部を切開する.

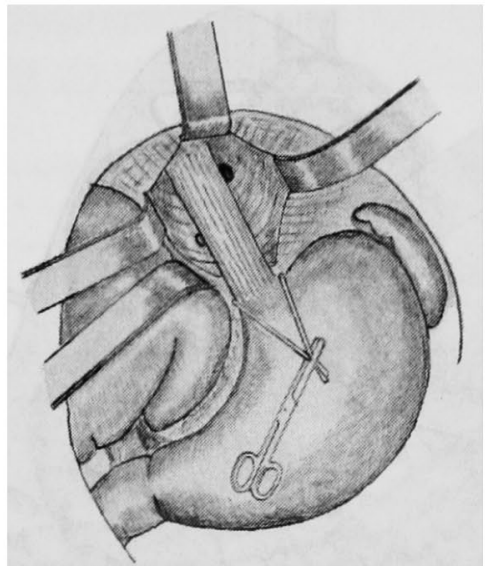

b. 裂孔部を開大して下綎隔の十分な視野を得る.

図 3 食道裂孔部の開大

（図3 a).His 角部にネラトンのカテーテルを通して 手前に引き，左右の迷走神程を切離する．左右の胸膜 を損傷しないように注意しながら食道を鈍的に豩離 し，胸部下部傍食道(No. 110)リンパ節，横隔膜 (No. 111）リンバ節および後綎隔（No. 112）リンバ節の廓 清を行なら，図3 bのように，腸筧を用いて綎隔を開 大すると十分な視野を得られる。また，必要に応じて 胸骨を板状鈎で強く前方に挙上すると，心を圧迫する ことなく手術野を扗大することができる，遊清が凧ん だら，食道を手前に引っ張りながら，癌の食道内進展 部より3〜 $5 \mathrm{~cm}$ 離れた所に直角 (食道) 鉗子をかけて, さらに，食道の鉗子からの滑脱を防ぐために，その口 側の左右端に 2 本の支持系をかけた後, 食道を切離す る (図 4).

次に，脾を後腹膜より䟝離し，脱転させる（図 5 ). こ5して脾門 (No. 10) および脾動脈幹 (No. 11) リ ンバ節の廍清を行ならと, 操作も容易であり且つ確実 に施行できる、この時点で脾動脈をその根部で結禁, 切離する. 同様に脾静脈を処理して,これらに沿って No. 9, No. 11およびNo. 10のリンパ節廊清を行な 5. 著者らは, 根治手術においては通常 R2の廊清を目 骠としているので, 早期癌でも摘脾を, 進行癌では脺 尾側・脾合併切除術を原則としている，苹は䐙尾側(切 除側）に腸鉗子をかけ，その頭側をメスで鋭的に切離 し，主萍管の断端には針系を赫けて禁し，出血血管 る針系で䋖合止血する，胼断端は埋没䋖合を行なっ て, 羘液の漏出に備える。この脾門部および脾動脈周 囲の操作と食道周囲および綎隔の操作はどららを先に 行なってる構わない.

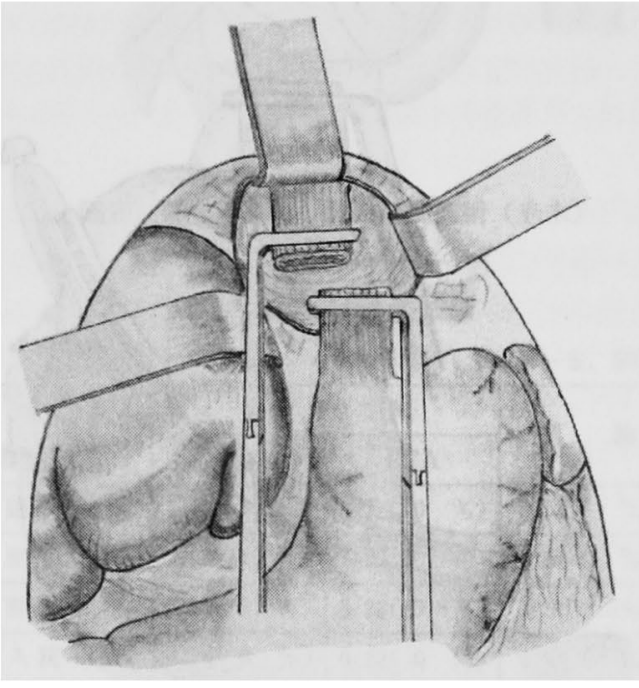

図4食道の切錐

以上の操作が終了したら，胃の切離に移る，胃の小 弯と大弯を処理した後, アーペッッを用いて噴門側胃 切除を行ならが，肛門側切除範囲も同様で，癌先端よ ク3〜 5cm 離れたところに切離線を置く（図 6 ）。腫痬 は小弯側に多いので小弯側を十分切離寸る，必要に応 して胃切開を加えて胃内腔を開放し，病巣の拡か门を 確認して切離線を決定する。 また，切除後直ちに切除 胃を開いて観察し，口側および肛門側断端の癌遺残に 対処する.

b）胃全摘術：噴門側胃切除術の場合と異なり胃大 網動脈を温存する必要はないので，本動脈を根部で結 禁・切離して，No. 6およびNo. 4d リンパ節の倣清を 


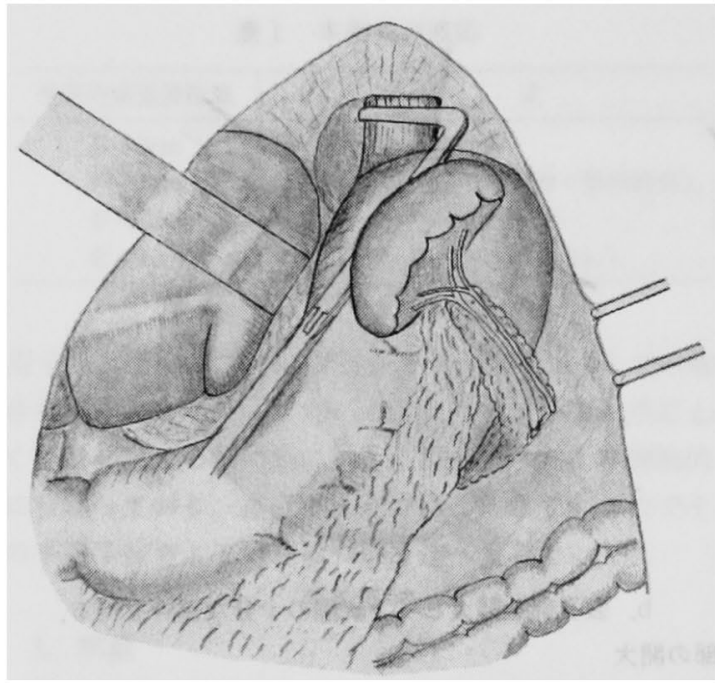

図 5 脾およU膻尾側の脱転

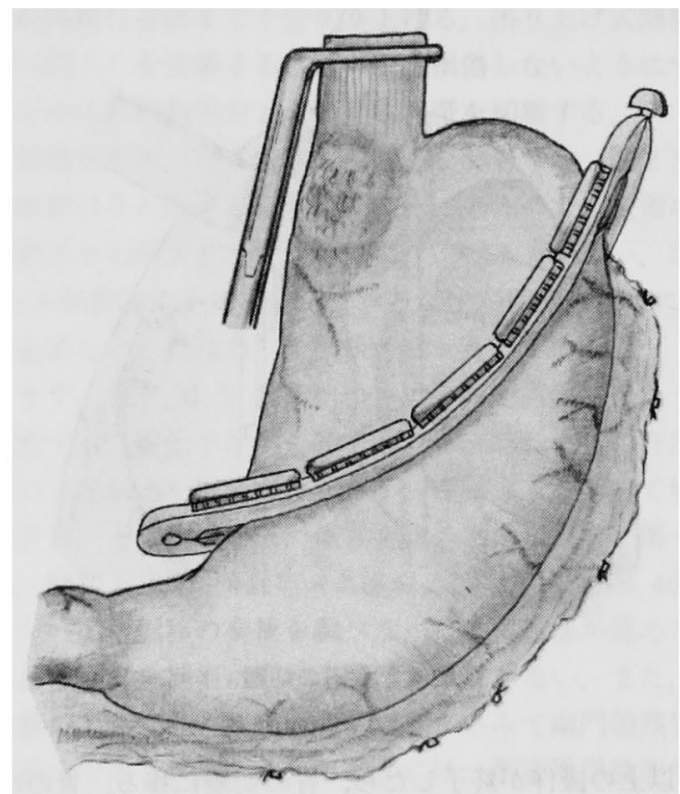

図6 胃の切離（喷門側胃切除術）

行な5.また, 必要に応じてNo. 15およびNo.14のリ ンパ節を遊清する。指腸授動術を施行し，右胃動 脈の処理およびNo. 13, No. 12 リンバ節廊清を行 なった後, 幽門輪の肛門側で小 Petz 胃腸䋖合器を用 いて十二指腸を切離し，その断端を埋没縫合する。そ の後の操作および順序は噴門側胃切除術の場合と全く 同様である。

残存食道端に癌遺残が疑われるものや食道内癌進展 が著明な例 $(\mathrm{E}>3 \mathrm{~cm})$ では十分な食道の切除と胸腔内

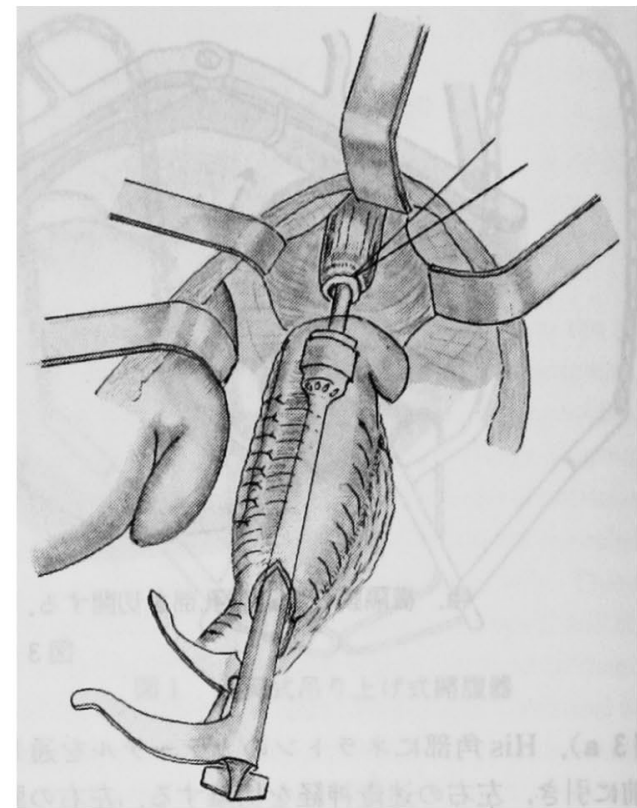

図 7 EEA による食道・胃端側吻合

リンパ節廊清を行なう必要があり，それには腹腔側か らの操作のみでは困難ないし不可能であるので，やは り右開胸的アプローチがよいり思われる.

3. 消化管再建法

a）噴門側胃切除術：幽門側胃が十分残る場合に は，食道・胃吻合を扣こなら，著者らは，残胃の大き さが幽門輪ないし幽門形成の部位から15cm 以上あれ ば，衍後逆流性食道炎の発生は極めて少なかったこ

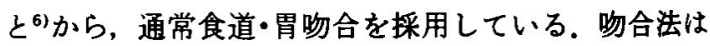
手䋖いおよび器械吻合のどちらす行なっているが, こ こでは器械吻合について述べる.

原則として Heinecke-Mikulicz 型幽門形成術を付 加している．まず幽門輪の上下にまたがる約 $3 \mathrm{~cm}$ の綎 切開を加え，図7のように、ここから EEA 型自動吻合 器を挿入し, 残胃の前壁で口側断端より約 $2 \sim 3 \mathrm{~cm}$ 肛 門側のところから自動吻合器の先端を胃壁外に出し， 予めこの部の胃壁に通してあった結禁糸で胃壁全層を しっかりと結禁, 固定した後, その先端に anvil を装着 する.ここで腸篦などを用いて綎隔を十分に開大して, 图7のよ5に anvil を食道断端に入れて，予め緟絡桻 合 running sutureしておいたタイクロン禾でしっか りと結禁，固定する．食道および胃の全層に吻合器の クリップがかかることを確認して器械吻合を行なら。 wing nut を回し, anvil と cartridge を密着させ,この 間に周囲の組織や異物が挟まらないよう注意する。こ 
のよ5に, 吻合は食道と胃の端側吻合で, 2 列の staple を有する EEAによる1層吻合を原則としている，器 械吻合終了直後に器械で切除された食道と胃の断端の 組織を検し，それが完全な輪になっておれば，吻合は 一応完全に行なわれたと考えてよい.そらでない場合 には，吸引管からの出血の有無を確認し，また，必要 に応じてィチレンブルー $5 \mathrm{ml}$ を生理食塩水 $20 \mathrm{ml}$ に溶 かしたものを注入して, 吻合部からの色素の漏出の有 無を確認しておく，漏出部が認められれば， 3 号絹系

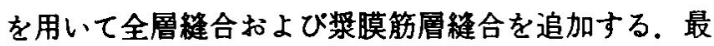
後に幽門形成術を施行する。形成術完成直前に，この 部位で経钼的减圧胃管と栄養管を操作して, 前者は先 端を食道・胃吻合部に，後者はその先端をTreitz 勒帯 から約 $30 \mathrm{~cm}$ の部位に置く。

b) 胃全摘術：Treitz 勒带より10－20cm の部位で 腸間膜を処理し，結腸間膜および食道裂孔部を通して 綎隔内へ空腸を挙上する。この間置空腸の長さ $(\rho$ 部分 を含むは全長 $50 \sim 60 \mathrm{~cm}$ であり，この間值空腸の切離 には腸管壁に入る末梢血管を 2 ～本処理するだけで 腸管に沿ら動脈弓は切離しないので, 間置腸管の血行 は十分温存できる，ただし，綎隔高位での吻合の場合 には，挙上する方の腸管の動脈弓を切離せざるを得な いこともある。この間置空腸の口側端から EEAの cartridge を内腔に捚入し，断端から $20 \sim 30 \mathrm{~cm}$ のとこ ろの腸壁から先端を出して，6号綟系で腸壁全層を結 愁・固定する。このように, 食道・空腸端側吻合を器 械吻合で行なら．次にこの断端を食道との吻合部から 約 $15 \sim 20 \mathrm{~cm}$ 離れた空腸脚に端側吻合する.これより さらに約 $10 〜 15 \mathrm{~cm}$ 離れたところで空腸を切断し，そ の口側端を十二指腸に端側吻合する，最後に，Treitz 勒帯より肛門側の断端と残存空腸とを端端吻合すると 再建が完了する (図 8 $)^{7)}$. 吻合完成直前に, 减圧胃管 と栄美管を経番的に誘導し，前者は先端を食道・空腸 吻合部に, 後者はTreitz 靱帯下の吻合部より約 $30 \mathrm{~cm}$ 肛門側に設置する。

\section{4. 閉腹}

腹腔内を温かい生理的食塩水で洗浄した後，ドレー ンを左側腹部から䐙断端または食道裂孔部に向かって 1 本, 右側腹部より Winslow 孔に向かって 1 本插入 して，閉腹する．なお，開腹時に切離した肝鎌状靯帯 および肝円勒帯を再び元のように腹壁に絴着しておく ことを忘れてはならない．閉腹時にこの修復を怠った ために，術後恐らく総胆管の屈曲，㨝れによると思わ れる高度の閉塞性黄疸をきたした症例を経験してい

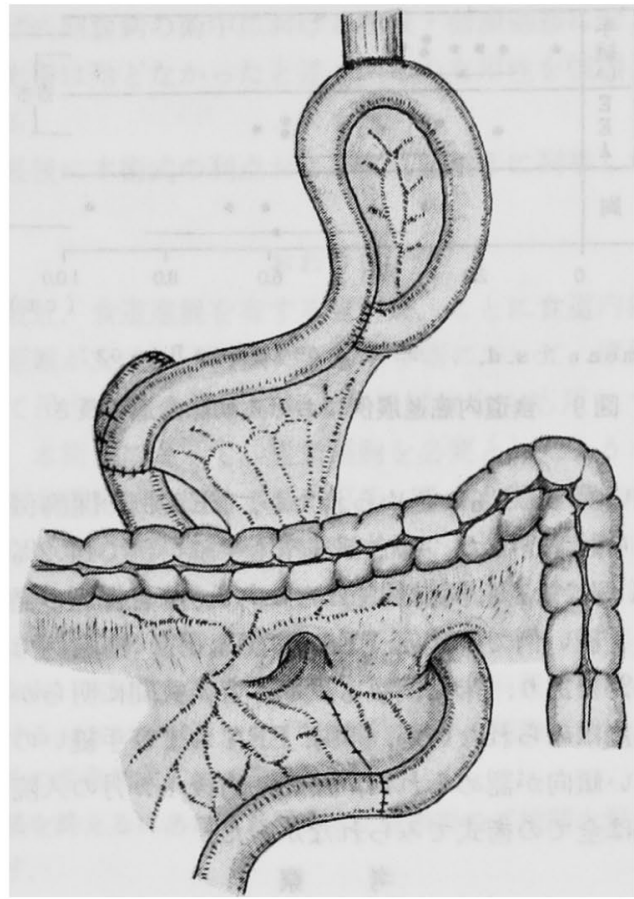

図 8 胃全摘後の $\rho$ 型空腸間置術（赤木）

\section{表 2 喷門癌の術後成縸}

(S. $56 \sim \mathrm{S} .58$ )

\begin{tabular}{|c|c|c|c|}
\hline 術工 & 非 & 胸 & \\
\hline & 手剩 い & EEA & $\Delta \rightarrow \overrightarrow{0}$ \\
\hline 绕合不全 & $1 / 14(7.1 \%)$ & $0 / 22\left(\begin{array}{ll}0 & \%\end{array}\right)$ & $0 / 5\left(\begin{array}{ll}0 & \%\end{array}\right)$ \\
\hline 吻合部狭窄 & $2 / 14(14.2 \%)$ & $2 / 22(9.1 \%)$ & $0 / 5\left(\begin{array}{ll}0 & \%\end{array}\right)$ \\
\hline 肺 合垪 症 & $1 / 14(7.1 \%)$ & $3 / 22(13.6 \%)$ & $1 / 5(20.0 \%)$ \\
\hline 入死亡 & $0 / 14\left(\begin{array}{ll}0 & \%\end{array}\right)$ & $0 / 22\left(\begin{array}{ll}0 & \%\end{array}\right)$ & $0 / 5\left(\begin{array}{ll}0 & \%\end{array}\right)$ \\
\hline
\end{tabular}

る.

\section{手術成績}

本術式を採用してから未だ 3 年余しか経過していな いので，術後近接成續について検討してみた，表 2 は 教室における過去 3 年間の噴門癌に対する手術成績を 示したものである. 非開胸例が36例で,このらち吻合 器非使用例 (手縫い) かi14例, 吻合器使用例 (EEA) は22例であり，開胸例は 5 例で全て右開胸であった。 このらち食道内癌進展例における切除食道（ホルマリ ン固定後）の長さの最長値と平均（図9）は，それそ れ手梿い例で $3.5 \mathrm{~cm}, 2.3 \pm 1.0 \mathrm{~cm}(\mathrm{n}=7), \mathrm{EEA}$ 例で $6.2 \mathrm{~cm}, 4.0 \pm 1.5 \mathrm{~cm}(\mathrm{n}=10)$, 開胸例では $9.5 \mathrm{~cm}, 5.9 \pm$ $2.5 \mathrm{~cm}(n=5)$ であった. 術後合併症のうち縫合不全は 


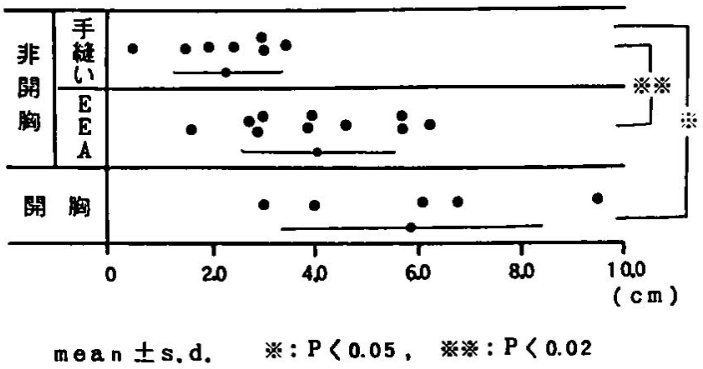

图 9 食道内富進展例における切除食道の長さ

手秚い例で7.1\%に認められたか，EEA 例と開胸例て はみられず，また，吻合部狭窄も手䋖い例で $14.2 \%$, EEA 例で9.1\%,開胸例ではなかった。肺合併症の発生 率は手敕い例で7.1\%，EEA 例で13.6\%，開胸例では

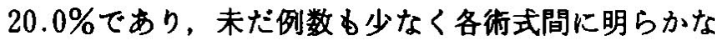
有意差はみられないが，開胸，EEA および手䋖いの順 に高い傾向が認められた。 また，術後 1 カ月の入院死 亡例は全ての術式でみられなかった。

\section{考察}

噴門癌では，縦隔内リンパ節転移は図10の上5にか なりの頻度に認められ，ことに，食道内癌進展のある ものではその頻度も高く899)，根治手術においてはこれ らのリンバ節の予防的廊清の意義は大きいと考光られ る。また，豊田らりは食道内進展が2 $\mathrm{cm}$ を超えるすので は胸腔内リンバ節転移率は $34.8 \%$ の高値を示したと述 へ，その廏清および断端癌遺残防止の目的で開胸すへ きであると結論している。

噴門癌の手術的フプローチの方法にも，左開胸経横 隔膜法 ${ }^{10)}$, 開腹十胸骨縦切開法 ${ }^{11}$, 左胸腹連続切開

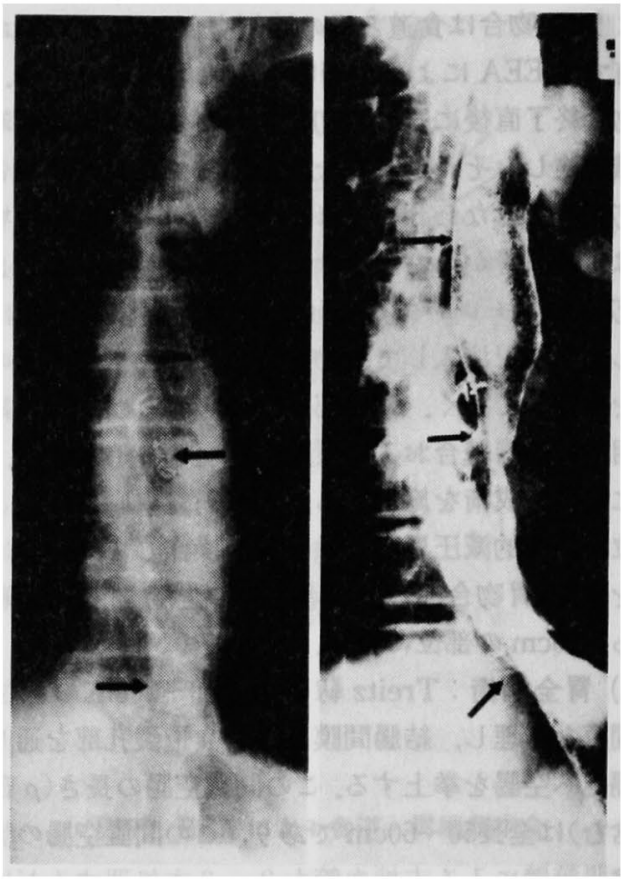

写真 1 本術式による綎隔内食道・胃吻合術後の X 線 写真であり，上段の矢印は気管分岐部，中段は吻合 部、下段は食道裂孔部を示寸。

法 ${ }^{121313}$ ，および右開胸開腹法1134があり，それぞれの利 点・欠点については末だ議論の多いところである。最 近，教室では噴門癌の手術において森岡式吊り上げ式 開腹器(图 1 $)^{2)}$ を使用している3)が，既に示した(图 3) よ5に腹空内からも十分な視野が得られるので，これ ら縦隔内のリンパ節ことに横隔膜（No. 111）リンハ 節，後縦隔 (No. 112) リソパ節拈よび胸部下部傍食道
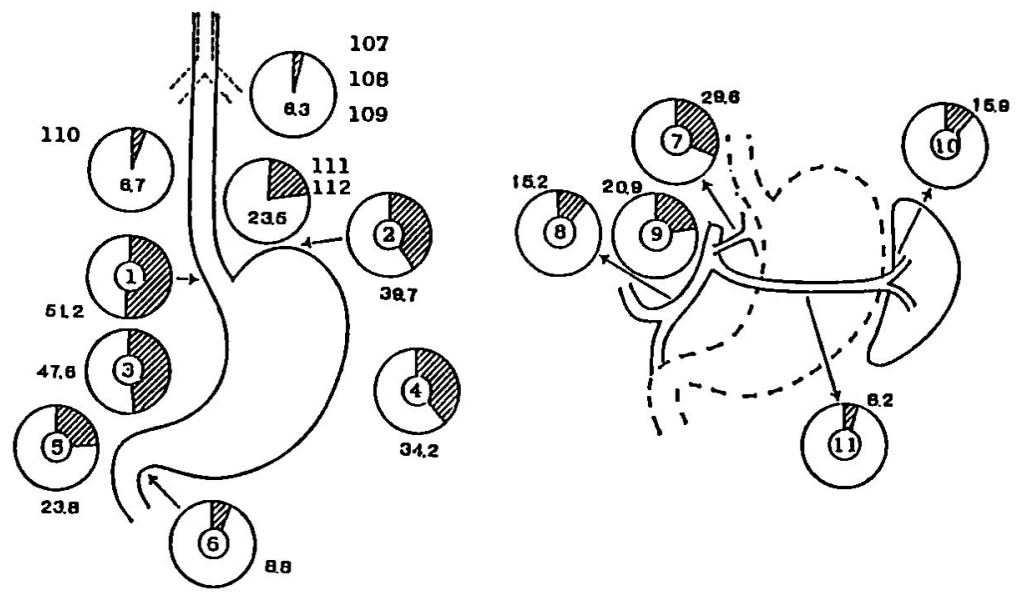

图10 上部胃要のリンパ節転移率（\%）（S. 41～S. 57） 


\section{表 3 本衍式の利点と欠点}

[利点]

1. 非閉胸的KNo. 110，111，112のリンパ節廊清が十分に しかあ容易にできる。

2. EEA を応用することにより，非閒胸的に広箅な食道( Ei および $\operatorname{Im}$ の一部)の切除および中部食道( $(\operatorname{Im}$ の部位) での吻合が可能である。

3.開胸手術に比へて传量が小さく、術啳呼吸機能に与える 影管少ない。

4,必要に応して，何時でる(右)開胸手術に切りかえること ができる。

[欠点]

1. No. 107，108，109の綎隔内リンパ節酣清が困難ないし 不可能である。

2. 開胸ことに右開胸手術に比へると食道の切除範囲が制 限される。

（No. 110）リンバ節の廓清が容易である。これより上 部のリンパ節の完全廊清は開胸的に行なわねばならな いので，その必要性が認められたときにはいつです開 胸操作を加之るべきである，著者らは開胸操作は全例 右開胸で行なっているが，その際でもNo. 110，111， 112の廓清は胸腔側からはむしろ困難であり,やはり腹 腔側より十分に行なっておくことが望ましい，噴門癌 の食道進展例に扔ける口側切除線は，一般に限局型で は腫場縁より2 -3cm，浸潤型では $4 \sim 5 \mathrm{~cm}$ 以上離す必 要があるといわれている(13)151 17)。 したがって，実際に は食道内進展距離が $3 \mathrm{~cm}$ 以上に及ぶものでは最低 5 8cm 以上の食道切除がなされねばならない，藤巻 $ら^{18)}$ 指摘するごとく，それ以上の食道切除は非開胸 的には不可能であると思われる。食道の切除範囲こと に切除食道の長さについては, 標本の収紑率の問題199 や個体差もあるので一概に論じることはできない。む しろ，切除食道の長さよりも，術後のX 線写真におけ る吻合部の高さで判定する方か，客観性があって都合 がよいと考えられる．写真 1 は噴門側胃切除後食道胃 吻合術に括ける術後 X 線造影所見であり，食道胃吻合 部の金属クリップが気管分岐部と横隔膜裂孔部との中 間の位置に認められる。

このよらに, 吊り上げ式開腹器と自動吻合器(EEA) を応用することによって，より厇範囲の食道切除とか なり高位（例えぱ気管分肢部直下の部位つまり $\operatorname{Im} の$ 高さ）で吻合が可能になった。

術後合併症のらち縫合不全の発生は現在のところ認 められず，術後肺合併症の発生率においても開胸例に 比較して良好な成績が得られている. 吉野ら ${ }^{200}$ も，吊り
上げ式開腹鈎の術中における呼吸・循環動態におよぼ す影響は殆どなかったと述へ，その有用性を強調して いる.

最後に本術式の利点括よび欠点を表 3 に列挙してお $<$.

\section{おわりに}

最近, 食道進展を有する噴門癌, ことに食道内癌進 展距離が $3 \mathrm{~cm}$ 以下の例に対する手術において，原則と して吊り上げ式開創器および器械吻合を応用してい る，本術式によって，従来開胸を必要としたような例 でも非開胸的に根治手術が可能になり，開胸操作を要 しないために術後の合併症む少なく，比較的良好な成 績が得られつつあるので，その術式の手術手技，利点 扣よび術後の近接成續について述べた。

なお，本論文の要旨は第 46 回日本臨床外科医学会総会に おけるシネシンボジゥム「噴門癌に対する開胸手術の適応 とその手術術式」にて発表した。

稿を終えるにあたり恩師赤木正信教授のご校閲を梁謝し ます。

\section{文 嗝}

1）三隅厚信，赤木正信, 池田佰紀他：下部食道噴門癌 に対する右開胸・開腹的フプローチ，日臨外会誌， $43: 1078-1081,1982$.

2）森岡恭彦，根本 茂：吊り上げ式開腹器, 外科, $45: 67-69,1983$.

3）三隅厚信, 赤木正信, 三隅克毅他：噴門癌手術に拉 ける吊り上げ式開腹器および器㳦吻合の応用，日 臨外会誌, 45：127, 1984

4）三隅厚信, 赤木正信, 馬場憲一郎他：噴門癌の外科 的治療における門題点一近側胃切除と胃全摘政の 比較一，日消外会誌，17:6-14，1984。

5）丸山圭一，北岡久三，平田克治他：噴門部癌に対す る手術術式の選択；根治性から，消外，6： 1425-1431, 1983.

6）赤木正信，三隅厚信，馬場憲一郎他：噴門側胃切除 後の障害と対策，消外，3：1689-1697，1980。

7）赤木正信，三隈厚信，前野正伸他：胃全摘後の再建 術，外科治療，51：721-726，1984.

8）磯野可一，鍋谷欣市，吉川正去他：噴門癌の特性 一とくに胸腔内リン八節転移について一，外科， $32: 457-463,1970$.

9）豊田澄男，太田博俊，大橋一郎他：食道・胃境界領 域癌の外科治療, 一とくに胸腔内リンバ節転移に ついて一，日消外会誌，13：165-171，1980.

10）武田良：左開胸経横隔膜 Approach による食道 
噴門癌の手術, 日外会誌, $79: 1237-1241,1978$.

11）菓根康行, 北村正次，小西俊郎他：下部食道噴門癌 手術における下部胸腔内リンバ節倣清, 手術, 38 ： 1047-1052, 1984.

12）秋山 详, 宮葓 光, 鶴丸昌彦他：左胸腹連続切開 法の利点, 日外会誌，79:1232-1236，1978.

13）西 满正，甲 孝，加地佐隆他：下部食道·噴門 部癌の進展様式アプローチの考方方，消外， 5 ： 1851-1859, 1982.

14）佐々木公一，武藤輝一：食道漫潤を伴亏噴門癌の

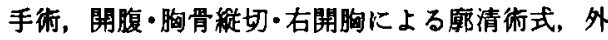
科診療, $26 ： 1510-1514 ， 1984$.

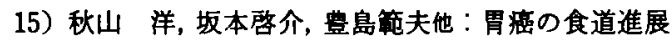
形式，胃之腸，7:801-808，1972.

16）龍口安彦：噴門部胃癌の臨床病理学的研究, 神戸
大医紀，39：215-242， 1979.

17）井口喍，杉町圭葴，神代鹃之介他：下部食道·噴 門癌手術術式の選択, 一特に口側, 肛門側切除簀囲 の埃討一，消外， $5: 1861-1866 ， 1982$.

18）藤巻雅夫, 唐木方昭, 簏 耕平他：口側切除端の䍃 残存例飞対する衍式の検討，消外，5：1881-1885, 1982.

19）秋山 洋, 阿曾弘一，牛山孝樹他：食道癌剔出僄本 の取扱いと収縮率，日外会誌，69:1633-1637， 1968.

20）吉野㹂一，稲田高男，奥沢星二郎他：噴門部胃癌に 対する非開胸術式，吊り上げ式開腹鈎による释横 隔膜的緃隔内操作による根治術, 日臨外会誌, 45: 127, 1984 .

\title{
APPLICATION OF THE PULLING-UP RETRACTOR AND AUTOSUTURE IN TRANSABDOMINAL SURGERY FOR CARCINOMA OF THE GASTRIC CARDIA
}

\author{
A. MISUMI, K. MISUMI, K. BABA, Y. YAGI, Y. INAMORI, Y. ATOBE, H. KONDO, \\ M. MAENO, S. TAKANO, K. HARADA, A. MURAKAMI, S. KATABUCHI, M. TANIMURA, \\ K. ARIMA, U. HONMYOU, S. MIZUMOTO, S. SHIMADA, M. MORIYASU \\ and M. MAEDA \\ 2nd Department of Surgery, School of Medicine, Kumamoto University \\ (Director: Prof. M. AKAGI) \\ H. SHIMAMURA and T. EGUCHI \\ Department of Surgery, Amakusa Central Hospital
}

Recently, application of a pulling-up retractor (divised by Morioka) to a transabdominal approach has facilitated dissection of the lymph nodes in the lower mediastinum and diffuse removal of the esophagus. In addition, application of an EEA type autosuture has made intramediastinal anastomosis at the middle or inferior esophagus possible.

At present, this procedure is commonly undertaken as the curative operation for carcinoma of the gastric cardia with esophageal invasion of less than $3 \mathrm{~cm}$. Out of 41 operations for carcinoma of the gastric cardia over the last three years, 36 were transabdominal procedures and the others were transthoracic ones. EEA was used in 22 of these 36 cases. Anastomotic insufficiency occurred in $7.1 \%$ of the sutured group, while none in the EEA or transabdominal group suffered from this complication. Pulmonary complications were noted in $7.1 \%$ of the sutured group, $13.6 \%$ of the EEA group and $20.0 \%$ of the transabdominal group.

We concluded that application of the pulling-up retractor and autosuture in transabdominal surgery is very useful for carcinoma of gastric cardia with esophageal invasion because this makes it possible to dissect the lymph nodes of the lower mediastinum and remove the esophagus sufficiently. 